\title{
MEMBUMIKAN NILAI-NILAI MODERASI AGAMA DI MASA PANDEMI (DALAM PERSPEKTIF IPS)
}

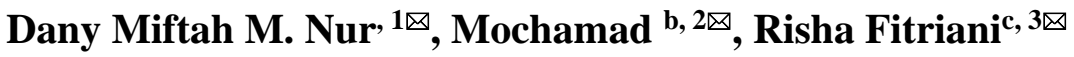

Institut Agama Islam Negeri Kudus

\section{Info Artikel}

Sejarah Artikel:

Disubmit November 2020

Direvisi November 2020

Diterima November 2020

\section{Keywords:}

Nilai-nilai, modernisasi agama, pandemi, perspektif IPS

\begin{abstract}
Abstrak
Tujuan tulisan untuk menyajikan tentang pentingnya pembelajaran yang ada di sekolahan (SD/MI) di masa pandemic, pandangan IPS dan Islam terapan dalam memandang Covid-19, serta untuk mengetahui eksistensi nilai-nilai moderasi Islam dimasa pandemic dalam perspektif IPS. Metode yang digunakan adalah metode kepustakaan Library Research, sedangkan pengumpulan data dilakukan dengan menelaah jurnal dan mengekploitasi beberapa buku dan dokumen-dokumen lainnya, serta sumber-sumber data dan informasi lainnya yang dianggap relevan dengan kajian. Dalam pembahasan kali ini mengupas ada beberapa cara dalam membumikan nilainilai moderasi agama dalam perspektif IPS, yang mana banyak sekali permasalahan yang menyangkut kehidupan masyarakat Indonesia dengan adanya wabah yang sedang menyebar keseluruh Indonesia. Dengan adanya wabah covid-19 menjadikan masyarakat melalaikan nilai-nilai dalam moderasi agama. bahwasannya moderasi agama yang dimaksud adalah nilai-nilai yang universal. Sedangkan penanaman nilainilai yang terkandung melalui jalur pendidikan. Sehingga, dengan pentingnya menanamkan nilai-nilai moderasi agama dalam proses pendidikan itu ditunjukkan agar peserta didik memilki way of life (pandangan hidup) dalam menghadapi kehidupan seperti sekarang ini.

Abstract

The purpose of the paper is to present the importance of learing in schools (SD/MI) during the pandemic, the perspective of IPS and applied Islam in viewing Covid-19, and to find out the existence of Islamic moderation values during the pandemic in the perspective of IPS. The method used is the literature method (Library Reaserch), while date collection is done by examining jounals and exploring several journals, books and other documentary documents, as well as other sources of date and information that are considered relevant to the study. In this discussion, there are several ways to ground the value of religious moderation in the perspective of IPS, which is a lot of problems relating to the social life of Indonesian society with the outbreak that is spreading throughout Indonesia. With the plague, people neglect the values of Islamic moderation does not mean that Islamic moderation is universal values. While the inculcation of the values contained through education. So that the importance of instilling values in the process of Islamic education is shown so that students have a way of life in facing their lives as they are today.
\end{abstract}

(C) 2020 Universitas Negeri Semarang

\footnotetext{
Alamat korespondensi:

Institut Agama Islam Negeri Kudus

E-mail: danymiftahmnur@gmail.com,

kampretcarrman@gmail.com, rishafitriani90@gmail.com
}

ISSN 2252-7133

E-ISSN 2548-4648 


\section{PENDAHULUAN}

Kesulitan yang saat ini menimpa Indonesia dalam menjaga ketentraman masyarakat tidak hanya dari wabah Covid 19 saja, melainkan juga dari banyaknya perbedaan yang ada, salah satunya dari segi agama. Menurut (Hani dan Ashif, 2020), dalam penjalanan peribadatan disetiap agama pasti ada perbedaan yang ada. Dalam agama islam pun begitu. Adanya empat madzhab tersebut merupakan representasi perbedaan dalam Islam yang mana antara satu dan yang lainnya. Terdapat perbedaan dalam prektek pengamalan syariat di dalam Al-qur'an dan Sunnah. Hal tersebut karena perbedaan ijtihad para madzhab yang tidak sama. Sehingga hasil berijtihad tadi berupa hukum Islam yang berbeda antara satu madzhab dengan madzhab yang lain.

(Darlis, 2017) juga memaparkan terkait perbedaan pandangan dalam suatu agama, bahwa, kontekstasi keberagamaan di Nusantara yang kerapkali terjadi gesekan antara kelompok dengan kelompok yang lain yang mana di antaranya disebabkan oleh perbedaan paham keagamaan dan paradigma berpikir. Kelompok tersebut dapat dipetakan menjadi kelompok ekslusivisme dan kelompok yang lain adalah liberalisme. Ekslusivisme adalah paradigma berfikir yang cenderung tertutup terhadap keanekaragaman, sementara liberalisme adalah sebaliknya, yaitu paham yang memperjuangkan kebebasan di semua aspek. Kedua kelompok tersebut seringkali memperlihatkan wajah Islam yang terkesan kurang bersahaja dan berkerahmatan.

Sehingga, secara sederhana saya, negara kita tertimpa permasalahan berat yang mendasar, permasalahan yang menyangkut kehidupan kemasyarakatan masyarakat Indonesia. Sebab, wabah yang belum menemukan faksinnya, daya jangkit yang tinggi. Begitu juga agama, agama merupakan rukum menjadi masyarakat Indonesia. Kalau agama sering mengeluarkan tindakan yang ekstrim maka kesejahteraan masyarakat terusik.

Dengan itu kehadiran moderasi Islam diharapkan menjadi sumbangsih jalan tengah untuk mengakhiri perseteruan ini. Moderasi Islam tidak berarti berada di posisi netral yang sering dialamatkan kepada kata tersebut. dan tidak juga diidentik dengan bias paradigma Barat yang cendrung memperjuangkan kebebasan yang keblabasan. akan tetapi moderasi Islam yang dimaksud adalah nilai-nilai universal seperti keadilan, persamaan, kerahmatan, keseimbangan yang dimiliki oleh agama Islam yang berakar dari sejarah dan tradisi Nabi dan Sahabat.

Moderasi Islam yang dimaksut kemudian dapat dijumpai dalam tiap disiplin keilmuan Islam, mulai dari aspek akidah, syariah, tasawuf, tafsir hadis dan dakwah. Sedangkan untuk penanaman nilai-nilai yang terkandung didalamnya haruslah melalui jalur pendidikan. Sebab pendidikan merupakan cermin kehidupan dalam menuai hidup. Ini diperjelas artikelnya (Sumartodan Emmi, 2019).

Pentingnya penanaman nilai dalam proses pendidiakan Islam ditunjukkan agar peserta didik memiliki way of life (pandangan hidup) dalam menghadapi kehidupannya. Dari paparan di atas kami menggunakan metode atau pendekatan kepustakaan (Library research),untuk itu kami akan melihat permasalahan di atas dari segi ke-IPS-an, Bagaimana pembelajaran yang ada di sekolahan (SD/MI) di masa pandemik ? Bagaimana pandangan IPS dan Islam terapan dalam memandang Covid-19 ? juga Bagaimana eksistensi nilai-nilai moderasi Islam dimasa pandemi dalam perspektif IPS?

\section{METODE}

Metode yang digunakan dalam kajian ini menggunakan metode atau pendekatan kepustakaan (Library Research), sesuai dengan bukunya (Zed Mustika 2003: 3) studi pustaka atau kepustakaan dapat diartikan sebagai serangkaian kegiatan yang berkenaan dengan metode pengumpulan data pustaka, membaca dan mencatat serta mengolah bahan penelitian. Dalam penelitian studi pustaka setidaknya ada empat ciri utama yang penulis perlu diperhatikkan diantaranya: Pertama, bahwa penulis atau peneliti berhadapan langsung dengan teks (nash) atau data angka, bukan dengan pengetahuan langsung dari lapangan. Kedua, data pustaka bersifat "siap pakai" artinya peneliti tidak terjun langsung ke lapangan karena peneliti berhadapan langsung dengan sumber data yang ada diperpustakaan. Ketiga, bahwa data pustaka umumnya adalah sumber sekunder, 
dalam arti bahwa peneliti memperoleh bahan atau data dari tangan kedua dan bukan data orisinil dari data pertama dilapangan. Keempat, bahwa kondisi data pustaka tidak dibatasi oleh ruang dan waktu. (Zed Mustika, 2003: 4 \& 5), berdasarkan dengan hal tersebut diatas, maka pengumpulan data dalam penelitian dilakukan dengan menelaah dan atau mengekplorasi beberapa jurnal. Buku, dan dokumen-dokumen (baik yang berbentuk cetak maupun elektronik) serta sumber-sumber data dan atau informasi lainnya yang dianggap relevan dengan penelitian atau kajian.

\section{PEMBAHASAN}

\section{A. Kondisi Pembelajaran IPS di Masa Pandemi}

Sebagaimana dengan kebijakan pemerintah, yang mana Negara Indonesia sedang dirundung yang namanya wabah virus corona atau yang disebut dengan virus covid-19. Wabah tersebut dinyatakan oleh WHO (World Health Organization) sebagai pandemi. Semua aktivitas sesuai aturan pemerintah harus memenuhi protokol kesehatan, salah satunya yaitu kebijakan dalam pendidikan. Aktivitas pendidikan saat ini berubah drastis dari tahun sebelumnya, pembelajaran saat ini yaitu menggunakan sistem Daring. Pasti banyak sekali dampak ataupun kendala-kendala dalam pembelajaran yang dilakukan secara daring. Misalnya seperti kondisi pembelajaran IPS di Masa Pandemi.

1. Tiga Wajah IPS yaitu Wacana Kritis, Tetangga dekat Ideology, Aplikasi Keilmuan dalam Kehidupan Seharihari.

Pembelajaran IPS di Indonesia memiliki tujuan untuk mengembangkan kemampuan melaksanakan ilmu-ilmu sosial yang mana pembelajaran IPS pada jenjang pendidikan sangat berbeda, waulaupun demikian pada dasarnya semuanya bermuara pada bagaimana membelajarkan pada peserta didik agar mampu memecahkan masalah-masalah social dan pengembangan pada diri mereka.
Sehingga idealnya peserta didik mampu menjawab tantangan tersebut.

Pertama, Wacana Kritis, yang mana melatih peserta didik untuk berfikir kritis dan menerapkan ilmuilmu social dalam kehidupan sehari-hari dapat dilakukan dengan metode debat, diskusi dan praktik lapangan.(Taufik Abdullah, (ed) 2006 : 2), dengan mengajarkan peserta didik untuk bias berfikir kritis dengan menerapkan ranah afektif, kognitif dan psikomotorik untuk bisa mengkritisi, mempertahankan pendapat dan terbiasa berfikir logis dengan melihat fenomena yang terjadi dalam kehidupan sehari-hari.

Kedua, tetangga dekat dengan Ideology, kosep pendidikan IPS sendiri memberi inspirasi terhadap kurikulum 1975, yang memang dalam banyak hal mengadopsi inovasi yang dicoba melalui kurikulum PPSP. Di dalam kurikulum 1975 pendidikan IPS menampilkan empat profil, yaitu 1). Pendidikan Moral Pancasila menggantikan Pendidikan Kewarga Negara sebagai suatu bentuk pendidikan IPS khusus yang mewadai tradisi citizenship transmission, 2) Pendidikan IPS terpadu untuk Sekolah Dasar, 3) Pendidikan IPS terkonfederasi untuk SMP yang menempatkan IPS sebagai konsep paying menaungi mata pelajaran Geografi, sejarah, dan ekonomi, 4) Pendidikan IPS terpisahpisah yang mencakup mata pelajaran sejarah, geografi dan ekonomi untuk SMA atau sejarah dan georafi untuk SPG. Konsep pendidikan IPS seperti itu tetap dipertahankan dalam kurikulum 1984 yang memang secara konseptual merupakan penyempurnaan dari kurikulum 1975. Penyempurnaan yang dilakukan khususnya dalam aktualisasi materi yang disesuaikan dengan perkembangan baru dalam masingmasing disiplin, seperti masuknya pedoman penghayatan dan pengalaman Pancasila sebagai materi pokok pendidikan Moral Pancasila sedangkan 
konsep pendidikan IPS itu sediri tidak mengalami perubahan yang mendasar. Jadi, dalam bukunya (Lubis, Maulana Arafat dan Toni, 2019 : 74-75) bahwasannya IPS memang tetangga dekat dengan ideology bahwa IPS ikut andil untuk mempelajari kehidupan bermsyarakat yang tercantum dalam sila-sila Pnacasila. Maka dari itu IPS tidak jauh dengan Ideology Negara Indonesia.

Ketiga, Aplikasi Keilmuan dalam Kehidupan Sehari-hari. Banyak sekali cara untuk mengaplikasikan keilmuan dalam kehidupan sehari-hari, banyak fenomena dan kejadian social yang dapat dipraktekkan, misalnya yaitu bermain peran,dramatisasi dan simulasi juga sangat tepat untuk menyikapi kasus-kasus social seperti penggusuran, bencana alam, perundingan kerjasama ekonomi, proses peradilan. (Taufik Abdullah (ed), 2006 : 3), Maka peserta didik dilatih untuk bisa mengaplikasikan keilmuannya dalam kehidupan sehari-hari pada pembelajaran IPS.

\section{Tujuan Pembelajaran IPS}

Tujuan IPS pada dasarnya yaitu untuk mempersiapkan peserta didik menjadi warga Negara yang baik. Tujuan pembelajaran IPS sendiri sangat terkait dengan tujuan kognitif, afektif, psikomotorik. Implikasinya, pembelajaran IPS idealnya mengembangkan strategi yang mampu mengembangkan ketiga ranah tersebut. Hal ini ditegaskan Peraturan Menteri Pendidikan Nasional Nomor 41 Tahun 2007 Tanggal 23 November 2007, Standar Proses untuk satuan Pendidikan Dasar dan menengah, bahwa proses pembelajaran tersebut harus interaktif, inspiratif, menyenangkan, menantang dan memotivasi peserta didik untuk berpartisipasi aktif serta memberikan ruang yang cukup bagi prakarsa, kreativitas dan kemudian sesuai dengan bakat, minat dan perkembangan fisik serta psikologi peserta didik IPS.(Saliman, Mukmin 2009:33), Selain itu juga untuk membentuk sikap yang rasional danbertanggungjawab terhadap masalah-masalah yang timbul akibat adanya interaksi manusia dengan lingkungannya.

3. Pembelajaran IPS di Sekolah Berdasarkan Zonasi

Satuan pendidikan yang berada di daerah ZONA KUNING, ORANGE, DAN MERAH, dilarang melakukan proses pembelajaran tatap muka disatuan pendidikan dan tetap melanjutkan belajar dari rumah (BDR). Pemerintah daerah, kantor wilayah Kementrian Agama Provinsi dan atau kantor Kementrian Agama Kabupaten atau Kota sesuai dengan kewenangannya pada ZONA HIJAU dapat melakukan pembelajaran tatap muka disatuan pendidikan yang sudah memenuhi semua daftar periksa dan merasa siap. Proses pembelajaran di sekolah merupakan alat kebijakan publik terbaik sebagai upaya peningkatan pengetahuan dan skill. (Aji Syah Halal Rizqon 2020:396), akibat dampak dari virus ini maka pembelajaran di Indonesia dilakukan secara Online, oleh sebab itu pemerintah memberlakukan untuk tidak melakukan pembelajaran secara langsung. Jadi, mentri pendidikan saat itu memberikan kebijakan baru dengan menyarankan kepada pemerintah daerah untuk melakukan pembelajaran tatap muka dengan syarat dan ketentuan yaitu tetap mematuhi protocol kesehatan, selain itu mentri pendidikan juga memperbolehkan pembelajaran secara tatap muka dengan halnya bahwa kota tersebut sudah dinyatakan sebagai kota dengan Zona Hijau. Kompetensi dalam pembelajaran IPS yaitu ada kompetensi 1, kompetensi 2, kompetensi 3, dan kompetensi 4.

4. Pembelajaran IPS di Tiga Lingkungan Pada hakikatnya pembelajaran IPS dapat dilakukan di 3 lingkungan 
yaitu Keluarga, Sekolah, dan Masyarakat. Pembelajaran IPS diarahkan untuk melahirkan pelakupelaku social yang berdimensi personal misalnya berbudi luhur, disiplin, kerja keras, dan mandiri. Dimensi sosiokultural misalnya yaitu cinta tanah air, menghargai dan meestarikan karya budaya sendiri, mengembangkan semangat kebangsaan dan kesetiakawanan social, kepedulian terhadap lingkungan. Dimensi spiritual misalnya yaitu iman dan taqwa menyadari bahwa alam semesta adalah ciptaan Tuhan yang Maha Pencipta. Dan dimensi intelektualmisalnya yaitu cendekia, terampil, semangat untuk maju.(Anshori Sodiq, 2014 : 72) Bahwasannya seorang anak mendapatkan pendidikan pertama kali mereka dapatkan dilingkungan keluarga terlebih dahulu bagaimana orangtua mengajarkan pendidikan kepada anakanaknya, setelah itu baru ke sekolah, anak juga mendapatkan pendidikan di lingkungan sekolah yang mana pendidikan itu diajarkan oleh guru nya, dan yang terakhir adalah masyarakat, anak diberikan pendidikan untuk diterapkan dimasyarakatnya.

5. Kendala-Kendala Pembelajaran Saat Pandemi

Teknologi informasi meliputi segalahal yang berkaitan dengan proses penggunaan sebagai alat bantu, manipulasi dan pengolaan informasi. Sedangkan teknologi komunikasi adalah segala sesuatu yang berkaitan dengan penggunaan alat bantu untuk memproses dan mentransfer data dari perangkat satu ke perangkat yang lain. Oleh sebab itu, teknologi informasi dan teknologi komunikasi adalah dua buah konsep yang tidak terpisahkan. Jadi teknologi komunikasi dan informasi mengandung segala kegiatan yang terkaitdengan pemprosesan, memanipulasi, pengolaan, pemindahan informasi antar media. (Soewarno, dkk 2016:28-39)
Menurut Arsyad media
berbasis computer merupakan cara menghasilkan atau menyampaikan materi dengan menggunakan sumbersumber yang berbasis mikroprosesor.pada dasarnya media berbasis computer menggunakan layar kaca untuk menyajikan informasi kepada siswa.(Azhar Arsyad, 2006 : 33), Oleh sebab itu teknologi sekarang sangat penting dijadikan sebagai alat informasi komunikasi dalam pembelajaran di sekolah, yang kita ketahui bahwa dengan adanya dampak covid-19 menjadikan pembelajaran sangat terganggu karena peserta didik tidak bisa melakukan pembelajaran tatap muka secara langsung, sehingga salah satunya jalan agar pembelajaran tetap dilakukan yaitu dengan menggunakan system daring atau online yang memanfaatkan teknologi informasi dan komunikasi untuk pembelajaran. Selain itu juga, tidak semua orang bisa memanfaatkannya secara langsung. Pasti banyak terjadi kendala-kendala yang menghambatnya seperti : tidak semua wilayah di Indonesia terjangkau internet, sinyal susah, Guru yang sudah berumur (Gaptek), orangtua yang sibuk, sarana dan prasarana di SD yang belum memadai (Pelosok).

\section{Solusi Pembelajaran IPS SD di Tengah} Pandemi

Penanganan dampak covid-19 dalam dunia pendidikan, seluruh steakholder harus bahu membahu ikut membantu menyelesaikan. Kondisi ini tidak boleh terlepas pandang dari kebijakan pemerintah dan pelaksanaannya operasionalisasi dilapangan.(Aji Syah Halal Rizqon, 2020:399), Jadi banyak sekali solusisolusi mengenai pembelajaran IPS SD ditengah pandemi misalnya yaitu : belajar daring, habitus dilingkungan keluarga (kesehatan, spiritual, sosial), diskusi dan tutor oleh orangtua, pengolahan budaya, update informasi tentang perkembangan ke IPS an, 
pemberian tugas secara berkala bagi peserta didik, pembuatan LKS bagi peserta didik, bleded learning, geoogle meet, geoogle classroom, elena, padlet, Microsoft teams, dan quizizz.com. Untuk link bealajar daring IPS juga disediakan didalam internet misalnya yaitu Hadapicorona.kemendikbud.go.id, ruang guru, rumah belajar, mejakita.com, Icando, dll.

\section{B. Bencana Dalam Bingkai IPS dan Islam Terapan}

Bicara mengenai bencana pastinya disetiap Negara, bahkan setiap orang pasti akan mengalami, (Novia Faradilla, dkk. 2016:56), dan bencana merupakan sebuah kejadian yang tidak dapat diduga apa lagi di sangak-sangka. Bencana bagi Indonesia adalah salah satu bentuk ancaman nonmiliter yang lebih mendominasi daripada ancaman militer. Melihat bencana Covid-19 yang terjadi di tahun 2020 ini merupakan kejadian bencana yang sangat langka yang di alami oleh bangsa Indonesia bahkan di luar Indonesia. Penyakit Coronavirus 2019 (COVID-19) adalah penyakit menular yang disebabkan oleh sindrom pernapasan akut coronavirus 2 (SARS-CoV-2). Penyakit ini pertama kali diidentifikasi pada Desember 2019 di Wuhan, ibu kota provinsi Hubei China, dan sejak itu menyebar secara global, mengakibatkan pandemi coronavirus 201920 yang sedang berlangsung.

Bencana dalam kajian integratif atau pembelajaran terpadu tentunya terdapat beberapa bidang yang yang mengkaji, diantaranya adalah ilmu, agama dan budaya. Dalam bidang ilmu bencana sering dikaitkan dengan kekuatan-kekuatan spiritual. dalam bidang agama bencana sering dikaitkan dengan sifat-sifat manusia, seperti sabar, tabah, ikhlas dll. Sedangkang dalam bidang budaya bencana sering dikaitkan dengan kearaifan lokal (Local Wisdom) yang menjadi kebiasaan/tradisi yang kepercayaan di daerah/wilayah yang terkena bencana tersebut. Selain dalam kajian integratif bencana juga bisa dikaji dalam bingkai ilmu IPS, mulai dari kajian sosiologi antropologi, geografi, dan sejarah. Dalam bingkai sosiologi antropologi bencana sering dikaitkan dengan aktifitas atau interaksi antara manusia dengan alam yang saling mempengarui. Dalam bingkai ilmu geografi bencana sering dikaitkan dengan kondisi lokasi atau kondisi permukaan bumi yang digunakan makhluk hidup dalam beraktifitas.(Abdus Sair, 2018:8), Sedangkan dalam bingkai sejarah bencana dikaitkan dengan kejadian-kajadian atau bencana yang pernah diterjadi dimasa lalu, Hanya saja manusia memandang bencana alam itu adalah hukuman dan simbol kemarahan dari dewa-dewa.

Kajian-kajian tersebut tentunya tidak lepas dari adanya respon masyarakat mengenai bencana yang sedang terjadi. Seperti contoh Ketika Merapi meletus, ada berbagai penjelasan yang diberikan oleh warga masyarakat di yogyakarta. ada yang menafsirkan peristiwa tersebut sebagai azab atau hukuman dari yang Maha kuasa, Sebagai wujud dari kegiatan makhluk halus di gunung Merapi yang sedang duwe gawe, dan ada juga yang penafsiran bahwa Peristiwa alam biasa yang memang tidak dapat dicegah, tidak dapat diperkirakan, tetapi dengan cara tertentu akibat buruknya dapat dielakkan. jika dikaitkan dengan kondisi bencana covid-19 di tahun 2020 ini, respon masyarakat dalam hal jiwa sosial juga sudah semakin meningkat. (Marion Couldrey dan Tim Morris, 2005:9), Masyarakat sipil telah memberikan kontribusi yang luar biasa untuk upayaupaya pemberian bantuan dan pemulihan. Kontribusi yang sampai saat ini terjadi salah satunya adalah membagikan masker gratis, pemberian semangat kepada korban covid-19 dll.

Respons masyarakat terhadap suatu bencana tentunya sangat perlu di istiqomahkan, agar selalu tercipta kedamaian dalam suatu kelompok masyarakat serta negara itu sendiri tentunya. Seperti yang dilakukan oleh lembaga pendidikan IAIN Kudus, IAIN Kudus selalu hadir dari masyarakat oleh masyarakat dan untuk masyarakat.sesuai dengan visi dan misi 
IAIN Kudus yaitu mengembangkan Islam Terapan untuk kemaslahatan dan kemajuan bangsa dan negara. Untuk Menuju Gerbang Pengembangan Islam Terapan dengan dasar keilmuan islam yang Humanity, Applicability serta Productivity melalui penyelenggaraan pendidikan, penelitian, dan pengapdian masyarakat. Dengan berlandaskan Normatif - Lafal Quli - Dalil Qur'an seperti dalam QS. Al-Baqarah Ayat 45, QS. Hud Ayat 82, QS. Al Isra Ayat 16) dan Landasan Teori atau Dalil Quli (Prinsip Hidup) serta landasan Tahfidz Quli atau Nilai Hidup - Untuk Bangkit Hidup (New Normal).

Melihat pembahasan di atas dapat ditarik benang merah bahwa bencana covid19 merupakan bencana alam yang perlu dilawan tetapi juga jangan sampai dianggap remeh, karna kita juga tidak tahu kapan bencana menghampiri kita dan kapan juga bencana menjauhi kita. Tetapi hal yang perlu ditingkatkan disini adalah bagaimana kita sebagai makhluk sosial dalam merespons positif mengenai terjadinya bencana yang terjadi di Indonesia dan Negara-negara di luar Indonesia. Terutama kita sebagai mahasiswa Prodi IPS IAIN Kudus, bukan tidak mungkin kita harus menjadi Hablum Minnallah \& Hablumminnas yaitu sebagai Pelaku Utama (Inteligence Social Actors) dan Good citizenship atau warga Negara yang baik, serta Problem Solving penengah dalam menyelasikan konflik-konflik yang terjadi di masyarakat.

\section{Eksistensi Moderasi Agama di Masa Pandemi dalam Perspektif IPS \\ Masa pandemi covid-19 2020} merupakan masa dimana orang jawa jawa menyebutnya dengan sebutan "Paceklik" yang artinya Tidak dapat dipungkiri terjadinya pandemi covid-19 banyak berpengaruh terhadap keseimbangan hidup di Negara Indonesia. Bahkan, tidak hanya negara indonesia, tetapi negara-negara di luar Indonesia juga merasakan hal yang serupa. Mulai dari masalah pendidikan, ekonomi yang terjadi di masa pandemi covid-19, Indonesia yang dikenal sebagai negara multicultural tentunya harus mewanti-wanti terjadinya masalah di bidang keberagaman Indonesia terutama dimulti agama. Karena belakangan ini konflikkonflik yang terjadi di Indonesia banyak yang bernuansakan agama, terutama di dalam agama Islam. Agama Islam sediri di Indonesia sangatlah mendominasi, jika tidak di dasari oleh rasa toleransi yang tinggi maka bukan tidak mungkin akan rentan terhadap masalah-msalah yang berkedok agama terutama agama islam.

Melihat penjelasan diatas sangat setuju kiranya Indonesia mengusung gerakan moderasi beragama yang dipelopori oleh kementrian agama. Moderasi beragama penting dalam mengelola kehidupan beragama pada masyarakat Indonesia yang plural dan multicultural (Edy Sutrisno, 2019:324), Dari sini sangatlah jelas bahwa moderasi beragama sesungguhnya menjadi kunci terciptanya toleransi dan kerukunan, baik ditingkat lokal, nasional, maupung global. Pilihan untuk bermoderasi beragama disetiap masayarakat juga menjadi kunci kesimbangan demi terciptanya kedamaian di Negara Indonesia ini.

Prinsip-prinsip yang harus di tanamkan dalam bermoderasi beragama adalah Taawun/Tolong-menolong, Tawasuth/Ditengah, Tawazun/Seimbang dan Tasamuh/Toleransi. Berikut ini penjelasannya :

1. Taawun/Tolong-menolong

Ta'awun adalah tolong menolong sesame umat muslim dalam kebaikan.(Jirhanuddin, 2016:132), Ta'awun bisa dilakukan dimana saja dan kapan saja asalkan kita melihat saudara kita yang butuh pertolongan dan siap untuk menolongnya. Ta'awun tak seharusnya dipermasalahkan tentang siapa yang menolong dan siapa yang ditolong, terutama jika melihat dalam derajat, pangkat, dan harta duniawi. Ta'awun yang utama dilakukan dalam kebaikan dan bukan dalam keburukan.

2. Tasamusth/ditengah

Tawassuth berarti (sikap tengahtengah, tidak ekstrim /ghuluw - 
tatharruf, termasuk di dalamnya tidak berfaham liberal) sikap tengah yang berintikan kepada prinsip hidup yang menjunjung tinggi keharusan berprilaku adil dan lurus ditengah-tengah kehidupan bersama, tidak ekstrim kiri ataupun ekstrim kanan.(Soeleiman Fadeli, 2007:53) Sikap tengah yang berintikan kepada prinsip hidup yang menjunjung tinggi keharusan berlaku tidak memihak. Selain itu tengahtengah disini dapat diartiakan menjadi penegah dan penengarai konflik-konflik yang terjadi sehingga tetap tercintanya rasa damai.

\section{Tawazun/seimbang}

Tawazun atau seimbang dalam segala hal, terrnasuk dalam penggunaan dalil aqli (dalil yang bersumber dari akal pikiran rasional) dan dalil naqli (bersumber dari Al-Qur"an dan Hadits). Seimbang yang dimaksut adalah berlaku adil/mengutamakan keadilan kepada siapapun.

(Mohamad Fahri dan Ahmad Zainuri, 2019:99), Selain itu tawazun adalah pemahaman dan pengamalan agama secara seimbang yang meliputi semua aspek kehidupan, baik duniawi maupun ukhrawi, tegas dalam menyatakan prinsip yang dapat membedakan antara inhira, (penyimpangan,) dan ikhtilaf (perbedaan).

4. Tasamuh/Toleransi

Tasamuh (toleransi), yaitu
mengakui dan menghormati
perbedaan, baik dalam aspek
keagamaan dan berbagai aspek
kehidupan lainnya.(Mohamad Fahri
dan Ahmad Zainuri, 2019:99)
Prinsip-prinsip moderasi agama
yang begitu jelas, tinggal kita dalam
mempraktekan ke dalam dunia nyata.
Dengan tujuan prinsip-prinsip tersebut
tidak hanya sebatas prinsip, tetapi juga
dapat terealiasi dengan baik juga. Sesuai
prinsip-prinsip diatas berikut ini cara
mudah mempraktekannya dalam
masyarakat multikultural:

1. Memperkuat dan meningkatkan sikap gotong-royong di masyarakat

2. Menumbuhkan dan memunculkan sikap toleransi di masyarakat yang majemuk

3. Mempererat rasa kesetiakawanan kepada sesama masyarakat tanpa memandang latar belakang kawan.

4. Memperkuat integrasi sosial di setiap individu

5. Memberikan solusi atau saran serta menjadi penengah terhadap problem-problem yang terjadi di masyarakat.

Bentuk-bentuk pempraktekan diatas tentunya harus diikuti dengan sikap warga masyarakat yg memiliki kepekaan sosial dan budi pekerti pekerti/akhlak yg baik agar dapat tercipta masyarakat yang sosiality independent Society (SIS) atau bisa dikatakan masyarakat yang mandiri dan bejiwa sosial tinggi.

Dalam membumikan eksistensi nilai-moderasi agama di tengah masyarakat tentunya terdapat ilmu pengtahuan yang berperan penting dalam terciptanya moderasi Bergama di setiap masyarakat, salah satu ilmu tersebut adalah ilmu IPS. Prinsip dasar dari ilmu IPS sendiri adalah menjadi aktor-aktor sosial yang cerdas (Inteligence Social Actors), selain itu adalah Menjadi warga negara yang baik ( good citizenship). IPS merupakan integrasi dari ilmu-ilmu sosial dan humaniora unruk tujuan pengajaran dalam pendidikan kewarganegaraan. Suwito Eko Pramono (2013) dalam bukunya menjelaskan bahwa IPS merupakan mata pelajaran yang terdapat di kurikulim sekolah, tertama yang mempelajari hubunganhubungan antar manusia dan dipandang paling penting dalam mengembangkan warga Negara yang bertanggung jawab (Suwito Eko Pramono, 2013:14).

Dikaitkan dengan masa pandemi covid-19 yang melanda Negara Indonesia dan Negara-negara lain di dunia, lalu bagaimana yang harus 
dilakukan oleh ilmu IPS?. Berikut ini catatan ke-IPS-an yang dapat di praktekkan :

1. Menggencarkan edukasi dan sosialisasi pola hidup sehat

2. Menggencarkan edukasi dan sosialisasi pencegahan penyakit pandemi

3. Kontrol sosial penegakan aturanaturan pemerintah

4. Gotong-royong ketika ada warga yang terdampak penyakit pandemi

5. Integrasi sosial antara warga dan pemerintah setempat terkait penanganan penyakit pandemi

6. Mulai memikirkan rekayasa sosial untuk pemulihan sosial-ekonomi masyarakat yg terdampak.

Inti dari pembahasan diatas adalah kunci untuk mengatasi berbagai problem sosial khususnya pada masa pandemi adalah Komunikasi masyarakat atau saling menjalin hubungan silaturahim, Sinergisitas, Kolektivitas dan integrasi sosial. Dari situ dapat disimpulakan bahwa masyarakat yang notabennya adalah masyarakat sosial harus menjadi pelopor dalam terciptanya sikap moderasi agama di masyarakat. Terutama mahasiswa yang melakoni Progam Studi IPS, memang mau gak mau harus menjadi pelopor utama dalam terciptanya masyarakat yang moderat. Lingkup kecil yang bisa dilakukan oleh mahasiswa Progam Studi IPS adalah kalangan masyarakat sekitar mereka sendiri, baik itu tingkat desa, kecamatan bahkan bisa dalam lingkup besar yaitu tingkat nasional

\section{SIMPULAN}

Sebagai makhluk sosial kita ditekankan harus percaya bahwa Indonesia merupakan Negara yang penuh akan keberagaman. Dari keberagaman inilah, perlu adanya peningkatan rasa moderasi agama antar umat beragama di Indonesia. Dengan tujuan, agar dapat menciptakan warga Negara yang memegang teguh 4 prinsip moderat, yakni: Ta'awun, Rawasuth, Tawazun, dan Tasamuth.

Masa pandemic ini, kita dapat membuktikan kepada khalayak umum. Bahwa kita dapat menjadi pelopor dalam menyikapi dan menjadi penengarai masalah-masalah yang hadir disekitar kita. Apalagi dimasa pandemic ini pendidikan harus dilaksanakan serba online. Sehingga, memunculkan masalah-masalah dimasyarakat seperti halnya: kesulitan jaringan, orangtua Gaptek, finansial dll. Oleh sebab itu, untuk mengatasi masalah-masalah tersebut, tidak ada kata selain bergerak...... bergerak.... dan bergerak......

Yakin. Optimis, Bisa, Totalitas Tanpa Batas.

\section{DAFTAR PUSTAKA}

Abdullah, Taufiq (ed). 2006. Ilmu Sosial dan Tantangan Zaman. Jakarta: Rajawali Press.

Arsyad, Azhar, 2006. Media Pembelajaran. Jakarta: Raja Grafindo Persada

Faradilla Novia, dkk. Efektivitas Pemanfaatan Wahana Tanpa Awak dalam Peliputan dan Penanganan Bencana, Jurnal Dialog Penanggulangan Bencana Vol. 7, No. 1 Tahun 2016

Fadeli Soeleiman. 2007. Antologi NU (Sejarah, Istilah, Amaliyah dan Uswah). Khalista Surabaya

Jirhanuddin, dkk. Manajemen Dana Iuran Rukun Kematian di Puntun Kota Palangkaraya, IAIN Palangka Raya. Jurnal Al-Qardh, Vol.2, No. 5, Desember 2016

Mukminin, dan Saliman. 2009. Teknologi Informasi dan Media Pembelajaran Ilmu Pengetahuan Sosial. Yogyakarta: FISE UNY

Mustika. Zed, 2003. Metode Penelitian Kepustakaan. Jakarta: Yayasan Obor Indonesia

Pramono Eko Suwito. 2013. Hakikat Pendidikan Ilmu Pengetahuan Sosial. Semarang: Widya Karya.

Rizqon Halal Syah Aji, Dampak Covid-19 pada Pendidikan di Indonesia: Sekolah, Ketrampilan, dan Proses Pembelajaran, 
Jurnal Sosial dan Budaya Syar-I FSH UIN Syarif Hidayatullah Jaakarta, Vol 7 No. 5 Tahun 2020

Sair Abdus. Bencana dan "Proyek" Kurikulum Kebencanaan di Sekolah, Journal of Urban Sociology Volume 1 No. 1 April 2018

Sutrisno Edy. Aktualisasi Moderasi Beragama di Lembaga Pendidikan, Jurnal Bimas Islam Vol 12 No. 1 Tahun 2019

Sodiq Anshori. Kontribusi Ilmu Pengetahuan Sosial dalam Pendidikan Karakter, UPBJJ-UT Surabaya, Jurnal Edueksos Vol III No. 2. Juli-Desember 2014

Soewarno dkk. Kendala-kendala yang di Hadapi Guru dalam Memanfaatkan Media Berbasis Komputer SD Negeri 10 Banda Aceh, Pendidikan Guru Sekolah Dasar
Universitas Syiah Kuala, Jurnal Pesona Dasar, Vol 2 No. 4 April 2016

Tim Morris dan Marion Couldrey. Forced Migration Review Tsunami: Belajar dari Respons Kemanusiaan, Sri Lanka: Colophon Media. Printed Lazergraphic (Pvt) Ltd. 2005.

Toni Nasution dan Arafat Maulana, dan Lubis. 2019, Konsep Dasar Pembelajaran Ilmu Pengetahuan Sosial. Yogyakarta: FISE UNY

Zainuri Ahmad dan Fahri Mohammad. Moderasi Beragama di Indonesia, Intizar, Vol 25 No.2, Desember 2019 